\title{
Gonzalo de Amézola. Esquizohistoria: la Historia que se enseña en la escuela, la que preocupa a los historiadores y una renovación posible de la historia escolar
}

Luis Fernando Cerri*

Buenos Aires: Libros del Zorzal, 2008

A obra Esquizohistoria faz parte da linha "Formación Docente" da Ediciones del Zorzal, uma nova editora argentina que tem centrado seu trabalho exatamente na área de atualização e formação dos professores das diversas áreas das disciplinas escolares. O título decorre de um artigo da década de 1990 publicado por Amézola juntamente com Ana Barleta, no primeiro número da revista Entrepasados, que hoje se caracteriza como uma das mais importantes revistas de história na Argentina. Esse artigo foi motivado pela magnitude das diferenças e contradições entre a visão do passado que os jovens ingressantes na Universidade de La Plata traziam do ensino médio, a que viam durante o curso e, de volta, a que deveriam enfrentar novamente com o planejamento para as atividades de estágio nas escolas. Amézola aponta que não se trata de erudição ou não, mas de natureza da história em cada âmbito, dentro de um processo de contínuo afastamento. O que explica esse espaço crescente entre a história na universidade e na escola é que "história acadêmica" tornou-se conhecimento especializado, e a escola sedimentou sua forma própria de conceber e de ensinar história, o que praticamente bloqueia a inovação com seus preceitos. Os termos esquizohistoria e historiofrenia indicam que essa fratura entre as histórias assumia e continua assumindo uma característica patológica, mesmo passados mais de dez anos entre aquele artigo e este livro. Mudaram radicalmente as características institucionais da educação argentina, mas permanece, todavia, a incerteza do valor educativo da história que se estuda na escola.

A primeira questão que cumpre responder é sobre o interesse da obra para os historiadores não argentinos, especialmente os historiadores brasileiros inte-

\footnotetext{
* Professor do Departamento de História e do Mestrado em Educação da Universidade Estadual de Ponta Grossa. Rua Conrado Schiffer, 60, bl. 4, ap. 304 - Vila Estrela. 84050-280 Ponta Grossa - PR - Brasil.1fcerri@uepg.br.
} 
ressados nas questões relativas ao ensino de História. O motivo mais imediato é a comparação de experiências históricas e temas atuais na área entre Brasil e Argentina, que a obra permite largamente, e que a realidade demanda de maneira cada vez mais intensa no contexto da integração cultural motivada pelo Mercosul, bem como pela integração latino-americana mais ampla.

A obra permite também a identificação das formas pelas quais os colegas argentinos equacionaram ou vêm equacionando problemas educacionais ou teóricos dentro de suas fronteiras, mas que na realidade são problemas comuns. Nessa vertente, poderemos talvez nos beneficiar da experiência já desenvolvida no enfrentamento daqueles problemas comuns, por caminhos distintos dos que viemos tentando ao longo do tempo.

Outro fator que torna o livro interessante para a comunidade de história no Brasil é o fato de permitir o conhecimento da bibliografia com a qual os colegas argentinos equacionam algumas das suas questões de interesse, que em alguns pontos são relativamente novas para nós, e em outros são velhas questões da reflexão didática da história tal como se realiza no Brasil, mas por outros caminhos e com outros autores. Esse conhecimento mútuo, que em muitos casos ainda está totalmente por fazer, tem grande potencial para impulsionar a pesquisa e a reflexão teórica e didática, assim como as contribuições dos pesquisadores à escola.

O livro está estruturado em duas partes. A primeira traça um histórico que permite vislumbrar como se refletiu na escola a visão dos historiadores da segunda metade do século XIX (ou como se constrói o que se pode chamar hoje de tradição do ensino de História). Se essa parte é útil ao professor de história argentino por ajudar a apreender a historicidade do seu métier, para o professor de história brasileiro e/ou pesquisador brasileiro do ensino de história, a narrativa desse percurso permite, além de conhecer melhor a experiência do país vizinho, ir reconhecendo e colecionando elementos que começam a sugerir universais do fenômeno social que é o ensino escolar da história, para além da especificidade das histórias particulares.

A segunda parte do livro é composta por um panorama crítico das alternativas de mudança para que a história no ensino médio se torne mais significativa. No final das contas, o desenho do problema central da obra é dado pelo esquadrinhamento e presença constante da diferença de natureza, ritmo e até mesmo de objeto entre a história ensinada e a pesquisada institucionalmente hoje, final de uma trajetória cujo início é marcado por uma quase identidade entre a história acadêmica e a história escolar.

Como se estabeleceu na escola uma visão de história tão resistente às 
inovações? Ao buscar as respostas a esse problema, Amézola indica as considerações de dois pesquisadores, Cuesta Fernández, que aporta o conceitochave de "código disciplinar" a partir da história social da cultura, e Pilar Maestro, cuja análise ocorre a partir da teoria da historiografia e de sua relação com aspectos psico-cognitivos e traz a reflexão sobre a grande influência das histórias gerais de construção de narrativas nacionalistas no século XIX para a criação de uma forma curricular para a história em diversos âmbitos educativos. Para Maestro, esse momento estabelece uma imagem tão forte da história e da nação - além do próprio conceito de história - que permanece marcada no imaginário coletivo. A primeira parte do livro é dedicada a testar essas teorias - desenvolvidas para o caso espanhol - na história argentina do ensino de História.

Depreende-se que, para o autor, a história do ensino de História na Argentina é periodizada de forma própria, ainda que seja balizada por alguns dos marcos da história política. Do surgimento da Argentina em 1810/1815 até 1930 , temos o período de constituição da disciplina (pois lá, como aqui, a criação da disciplina escolar coincide com a criação da disciplina científica) e de seu conteúdo, que poderia ser intitulado como "organização do panteão dos heróis". Outro período delimitado por Amézola vai de 1930 a 1955, marcado pelo nacionalismo e pelo peronismo. É a conformação do início de um combate pela história, revisionista, no qual os nacionalistas recuperam a imagem de Juan Manuel de Rosas e o incorporam ao panteão de heróis nacionais. Perón, aliás, tratou inicialmente de associar sua imagem à de Sarmiento, e no período posterior, de 1955 (queda de Perón) a 1976, a "desperonização" da educação teve como uma de suas marcas a associação de Perón a Rosas, caracterizando seu período como "segunda tirania". Nesse período, Amézola identifica o incremento da velocidade de distanciamento entre a história escolar e a história acadêmica. O outro período é o da segunda ditadura militar e da redemocratização, de 1976 a 1993 (ano da reforma educativa que institui os Contenidos Basicos Comunes), em que a psicologia cognitiva passa a ter um papel de peso na definição da história na escola. O período atual, por sua vez, é marcado pela reforma de 1993 e a intenção — não tão bem-sucedida — de aproximar ambas as histórias.

A segunda parte do livro dedica-se a apontar os principais temas da discussão do ensino de História na Argentina, que constituem as várias frentes a partir das quais se procura aproximar um pouco mais a história pesquisada e a história ensinada.

Amézola cita Zavala (Uruguai), Finocchio e Lanza (Argentina) para de- 
monstrar que hoje o conhecimento escolar no campo da história é um conhecimento à parte, composto de diversas fontes, e que as formas de promovê-lo em sala de aula são distintas, com predomínio de uma perspectiva positivista, complementada por um olhar idealista, com raros matizes de uma abordagem hipotético-dedutiva.

O autor coteja o tema do ensino de história com as proposições da psicologia e da pedagogia, opondo assim os graduados em história a pedagogos e psicólogos no enfrentamento das questões do ensino de história. Sem desprezar suas contribuições, reivindica o espaço do historiador no debate educativo, já que esse profissional é quem tem o domínio da matéria, sem o que as inovações técnicas ficam no vazio ou reforçam objetivos e práticas educativas já superadas epistemologicamente no campo da história e das ciências humanas.

Nessa chave interpretativa, o autor percorre as discussões sobre o ensino e a operação com os conceitos de tempo e espaço; a periodização; a complexidade do tempo histórico; os sujeitos históricos; sobre o que se busca com o ensino - "saber história" ou "saber historiar" —, e assim aborda o tema dos conteúdos procedimentais.

Com o debate dos conteúdos procedimentais, Amézola constrói o encerramento da obra, considerando o malefício que é a "procedimentalização" do ensino de história quando ocorre sem um profundo conhecimento da disciplina. Oferece ao professor-leitor uma sugestão de encaminhamento didático em que se aplica a construção do conhecimento histórico, atendendo, assim, à demanda pelos conteúdos procedimentais, sem perder de vista a complexidade do tempo histórico e das demandas epistemológicas contemporâneas da disciplina. Afinal, por mais que se distanciem pesquisa e ensino, continuam sendo essas as balizas comuns do trabalho de historiadores-professores ou professores-historiadores. Lidar com essa relação entre a história que se pesquisa e a história que se ensina, relação que para o autor chega às raias da patologia, é o desafio cotidiano desses profissionais.

Resenha recebida em fevereiro de 2009. Aprovada em março de 2009. 